\title{
25 \\ CRACKBERRIES: The Social Implications of Ubiquitous Wireless E-Mail Devices
}

\author{
Melissa A. Mazmanian \\ Wanda J. Orlikowski \\ JoAnne Yates \\ Sloan School of Management \\ Massachusetts Institute of Technology \\ Cambridge, MA U.S.A.
}

\section{RESEARCH FOCUS}

Mobile communication technologies provide a variety of opportunities for new forms of human interaction. Technologies such as e-mail, cell phones, and wireless email devices, often seen as overcoming spatial and temporal boundaries, have become standard features of contemporary organizational life. From the perspective of information professionals, these tools appear to wield direct influence on the daily experience of managing work, stress, and life. It is easy, however, to forget that such technologies are not used in a vacuum. Individuals make sense of communication technologies and decide when and how to use them in light of particular social, spatial, and temporal contexts. In this process, they take into account the characteristics of their tools, current social expectations, institutional norms, current and historical understandings of technology, and the everyday tasks in which they are engaged. The resulting patterns of use and their consequences (labeled "technologies-in-practice" by Orlikowski 2000) reflect the interaction of these multiple elements over time, affecting both the individuals interacting with the tools as well as the contexts within which their use is situated.

Focusing on the process of sensemaking and norm formation that accompanies the use of a new technology, this research explores how information professionals use wireless e-mail devices (WEDs) ${ }^{1}$ in their daily lives. As communication technologies

'Of these devices, BlackBerry, a product of Research in Motion (RIM), currently holds dominant market share and popular attention. On November 17, 2004, RIM announced it had reached 2 million users (http:/www.rim.net/news/press/2004/pr-17_11_2004-01.shtml). 
become increasingly mobile, the ability for people to stay connected expands into new temporal and physical settings. As individuals negotiate this potential, they find their use of WEDs challenging taken-for-granted expectations of connectivity, responsiveness, pacing, and etiquette. We are interested in understanding how individuals negotiate numerous and often conflicting organizational expectations, personal goals, and properties of a technology when enacting their technologies-in-practice. Further, we are investigating the implications of such use for both individual experiences and broader organizational structures.

\section{CONCEPTUAL GROUNDING}

Communication technologies appear to encourage new perceptions of time. According to scholars, individuals in modern society no longer experience time as the linear phenomenon instantiated during the industrial revolution (Zerubavel 1982) but rather as a relative, multiple, and dynamic experience. While reflecting nuanced distinctions, terms such as polychronic (Bluedorn et al. 1999; Cotte and Ratneshwar 1999; Schein 1985; Slocombe 1999), the illusion of simultaneity (Cooper 2001; Nowotny 1992), network time (Hassan 2003), or timeless time (Castells 1996) all highlight our current struggle to conceptualize how time is experienced in an age characterized by accelerated pace, ungrounded space, and expanded connectivity. While communication technologies do not cause these changes, people's engagement with the functionality of such technologies interacts with social and organizational expectations and engenders changes in the pace, space, boundaries and stress of work (Gripenberg 2004; Isaacs et al. 2002; Rennecker 2003; Sawyer and Southwick 2002). Given this dynamic, the mobile and asynchronous properties of WEDs may encourage individuals to experience these tools as both mediating and intensifying the experience of simultaneity, speed, and connectivity in the workplace.

While not specifically looking at the effects of communication technologies, scholars have found that the intensity and accelerated pace of information-driven organizations result in the sensation of a constant time famine that directly affects stress (Perlow 1999) and strain (Adams and Jex 1999; Teuchmann et al. 1999). Given the amount of scholarly attention focused on shifting experiences of time and space in the information age, it is surprising that relatively few studies have focused on how individuals actually incorporate mobile communication technologies into their daily lives. We thus know little about such questions as how individuals actually experience polychronicity, ${ }^{2}$ how communication technologies affect this dynamic, whether wireless devices increase or decrease perceived control over time famine, and potential implications of these changes.

Focusing a broad societal lens on technology, some scholars have explored similar questions by analyzing cell phone use in public spaces. Conceiving of cell phone use as a new category of communication that is mobile and constantly connected, a number

\footnotetext{
${ }^{2}$ Polychronicity is defined as the preference either to simultaneously engage in multiple tasks or to treat interruptions as equal to planned activities (Cote and Ratneshwar 1999, p. 184).
} 
of studies have examined individual experiences of connectivity as well as the social consequences of private conversations invading public space (Brown 2001; Cooper 2001; Katz and Aakhus 2002; Meyrowitz 1985). Research in this stream posits that by normalizing expectations of availability and eradicating markers of physical context, use of cell phones encourages both self-monitoring and the informal monitoring of others (Cooper 2001; Green 2001). Focusing on the relationship between individuals and their jobs, we build on this work in two ways. First, we focus on the recursive relationship between social expectations that shape individual action and the actions that shape and redefine organizational expectations. Second, we aim to flesh out how specific properties of WEDs enable and constrain both the patterns of use and subjective experiences of such use.

Wireless e-mail devices share many properties with cell phones, but unlike the cell phone, WEDs today are text-based, asynchronous, and silent. ${ }^{3}$ Because they lack the audible obtrusiveness of cell phones, some see wireless e-mail devices as appropriate for use during face-to-face interaction. As individuals use wireless e-mail devices in new situations, groups are forced to renegotiate norms of interpersonal interaction. Furthermore, the asynchronous nature of e-mail opens the door for new patterns of communication. Some popular narratives have cast mobile devices such as cell phones as organizational electronic leashes that harness people to organizations at all moments of their lives. The properties of WEDs are such that they may similarly be viewed as a more unobtrusive, although perhaps more insidious, monitoring device.

Finally, the introduction of WEDs into diverse interpersonal situations raises new issues. Tools such as wireless e-mail devices are used more and more in the physical presence of others, and yet no current work explores how such use may affect such interactions. The silent, mobile, and unobtrusive properties of WEDs facilitate use in face-to-face situations where individuals would be unlikely to talk on the phone or interact with a computer. How does the concept of social presence translate in situations where individuals are dividing their attention between face-to-face and virtual interaction? And, given this possibility for fractured presence, how do people negotiate physical and virtual interactions when the use of mobile communication technologies enters public spaces?

\section{DATA}

We are currently engaged in a field study examining the use of WEDs among mobile information professionals ${ }^{4}$ and their spouses. Focusing primarily on 2 research sites, we have conducted 69 semi-structured interviews to date, with 27 interviews at a

${ }^{3}$ While use of SMS (short message service) or text messaging via cell phones is popular in other parts of the world, it has not yet taken off in the United States, and is not perceived (at least by the professionals we talked to) to be comparable to wireless e-mail devices.

${ }^{4}$ The label mobile information professionals was defined by RIM as their initial target group. Information-based industries include law, venture capital, investment banking and consulting. Adoption of wireless e-mail devices among this group is extensive. 
small venture capital firm (including all 27 employees), 22 interviews at a mid-sized law firm (270 lawyers), and 8 interviews with spouses of these professionals. During the initial investigation for this research, we also conducted 12 additional interviews with assorted investment and venture capital professionals. Our principle sites were chosen as the basis of comparison for reasons of similarity (clear internal hierarchy, reliance on information, resource richness, and prevalence of travel) and difference (task, size, and power position with client).

Lasting from 30 minutes to 2 hours, interviews have focused on the adoption and use of the wireless e-mail devices: organizational context and expectations, organizational work practices and communication patterns, framing of the device, emergence and evolution of group norms associated with its use, incorporation of the device into everyday activities, experience of use while traveling, perceptions of connectivity, efficiency and productivity associated with its use, emotional responses (including stress) to use of the device, and work/family issues related to use. We are currently in the process of coding our initial interviews and have begun conducting follow-on interviews which involve examining a 24 to 48 hour period of messages sent and received by participants on their wireless e-mail devices.

\section{PRELIMINARY FINDINGS}

In our preliminary qualitative analysis of the interviews, we find that people differentiate wireless e-mail devices from other communication technologies in terms of patterns, norms, and experience of use. Furthermore, we find that the technologies-inpractice enacted with WEDs may be encouraging new interpersonal and organizational dynamics. Across the board, participants report constant and sustained interaction with their devices, at all hours and locations of their day. This interaction is informed by personal choices, perceived organizational expectations of constant availability, and work norms regarding appropriate use.

Most salient, and in contrast to the synchronous, point-to-point experience of talking on a cell phone, WEDs appear to allow users to watch and monitor conditions at work constantly and from a distance. In general, individuals experience carrying a WED as facilitating their ability to "stay in the loop" while controlling their terms of communication and catching problems early so as to avoid flare-ups. Rather than seeing this technology as an electronic leash, participants associate use of WEDs with stress relief and increased control over their work. In general, they experience WEDs as allowing them to monitor, rather than to be monitored.

Paradoxically, users also describe increasing expectations of responsiveness in themselves and others; for example, they report that they expect others to have read their messages within a matter of hours. They also sense increasing pressure to be constantly connected, available, and responsive. However, they view this increased pace and pressure as independent of their own use of WEDs. So far, our preliminary results do not suggest significant differences in these experiences along the lines of gender, hierarchy, or work/family situation, although we continue to investigate how these factors interact with user experience of WEDs. 
The sense of constant attention to WEDs (monitoring and interacting) appears to challenge group norms of behavior concerning where and how individuals are connected. While many feel that the relative silence and asynchronous nature of WEDs makes their own use of them in social situations less rude than use of cell phones and other audible mobile devices, individuals also report strong reactions to the inappropriate use of WEDs by others. Spouses, in particular, do not feel that the mobility provided by the device is valuable if the attention of their spouse is directed at the tool rather than toward the family. Use of WEDs during face-to-face meetings is common, but perceived differently by various members of an organization. Individuals note their desire to interact with the device during face-to-face situations, while acknowledging that such use diverts their attention from the immediate context. Both within and across the two organizations, we find overall agreement that the use of WEDs in face-to-face meetings is rude. Yet, we find little evidence that individuals share these opinions with each other or agree about the relationship between etiquette and actual use. We will continue to examine the effects of WEDs on interpersonal relations and organizational effectiveness, and plan to build exploratory theory about the social implications for individuals and organizations of the use of these devices.

\section{ACKNOWLEDGMENTS}

This research is supported by a grant from the National Science Foundation under award number IIS-0085725.

\section{REFERENCES}

Adams, G. A., and Jex, S. M. "Relationships between Time Management, Control, Work-Family Conflict, and Strain," Journal of Occupational Health Psychology (4:1), 1999, pp. 72-77.

Bluedorn, A. C., Kalliath, T. J., Strube, M. J., and Martin, G. D. "Polychronicity and the Inventory of Polychronic Values (IPV): The Development of an Instrument to Measure a Fundamental Dimension of Organizational Culture," Journal of Managerial Psychology (14:3/4), 1999, pp. 205-231.

Brown, B. "Studying the Use of Mobile Technology," Chapter I in Wireless World: Social and Interactional Aspects of the Mobile Age, B. Brown, N. Green, and R. Harper (Eds.), London: Springer, 2001, pp. 3-14.

Castells, M. The Rise of the Network Society, Oxford, UK: Blackwell Publishers Ltd., 1996.

Cooper, G. "The Mutable Mobile: Social Theory in the Wireless World," Chapter 2 in Wireless World: Social and Interactional Aspects of the Mobile Age, B. Brown, N. Green, and R. Harper (Eds.), London: Springer, 2001, pp. 19-31.

Cotte, J., and Ratneshwar, S. "Juggling and Hopping: What Does it Mean to Work Polychronically?," Journal of Managerial Psychology (14:3/4), 1999, pp. 184-205.

Green, N. "Who's Watching Whom? Monitering and Accountability in Mobile Relations," Chapter 3 in Wireless World: Social and Interactional Aspects of the Mobile Age, B. Brown, N. Green, and R. Harper (Eds.), London: Springer, 2001, pp. 32-44.

Gripenberg, P. "Virtualizing the Office: Micro-Level Impacts and Driving Forces of Increased ICT Use," Information Society and the Workplace, T. Heiskanen and J. Hearne (Eds.), London: Routledge Taylor \& Francis Group, 2004, pp. 103-125. 
Hassan, R. "Network Time and the New Knowledge Epoch," Time \& Society (12:2/3), 2003, pp. 225-241.

Isaacs, E., Walendowski, A., Whittaker, S., Schlano, D., and Kamm, C. "The Character, Functions, and Styles of Instant Messaging in the Workplace," Conference on Computer Supported Cooperative Work, New York: ACM Press, 2002, pp. 11-20.

Katz, J. E., and Aakhus, M. A. "Conclusion: Making Meaning of Mobiles-A Theory of Apparatgeist," Chapter 19 in Perpetual Contact, J. E. Katz and M. A. Aakhus (Eds.), Cambridge, UK: Cambridge University Press, 2002, pp. 301-318.

Meyrowitz, J. No Sense of Place: The Impact of Electronic Media on Social Behavior, New York: Oxford University Press, 1985.

Nowotny, H. "Time and Social Theory: Towards a Social Theory of Time," Time \& Society (1:3), 1992, pp. 421-454.

Orlikowski, W. "Using Technology and Constituting Structures: A Practice Lens for Studying Technology in Organizations," Organization Science (11:4), 2000, pp. 404-428.

Perlow, L. A. "The Time Famine: Toward a Sociology of Work Time," Administration Science Quarterly (44:1), 1999, pp. 57-81.

Rennecker, J. "Anticipating the Unanticipated Consequences of Instant Messaging (IM) for Individual Productivity," Sprouts: Working Papers on Information Environments, Systems and Organizations (3:3), 2003, Article 7.

Sawyer, S., and Southwick, R. "Temporal Issues in Information and Communication Technology-Enabled Organizational Change: Evidence From and Enterprise Systems Implementation," The Information Society (18), 2002, pp. 263-280.

Schein, E. H. Organizational Culture and Leadership, San Francisco: Jossey-Bass, 1985.

Slocombe, T. E. "Applying the Theory of Reasoned Action to the Analysis of an Individual's Polychronicity," Journal of Managerial Psychology (14:3/4), 1999, pp. 313-323.

Teuchmann, K., Totterdell, P., and Parker, S. K. "Rushed, Unhappy, and Drained: An Experience Sampling Study of Relations between Time Pressure, Perceived Control, Mood, and Emotional Exhaustion in a Group of Accountants," Journal of Occupational Health Psychology (4:1), 1999, pp. 37-54.

Zerubavel, E. "The Standardization of Time: A Sociohistorical Perspective," The American Journal of Sociology (88:1), 1982, pp. 1-23.

\section{ABOUT THE AUTHORS}

Melissa Mazmanian is a doctoral student in the Organization Studies Group at the Sloan School of Management, Massachusetts Institute of Technology. Her research focuses on the experience of information technologies as used in practice. She examines the role of organizations in shaping micro behaviors of technological use, the effect of such behaviors in shaping organizational structure, communication, and practice, and the individual experience of integrating new technologies into everyday life. In 2002, Melissa received a Master's in Information Economics, Management and Policy from the University of Michigan. She can be reached atmelmaz@MIT.EDU.

Wanda J. Orlikowski is a professor of Information Technologies and Organization Studies at the Sloan School of Management and the Eaton-Peabody Chair of Communication Sciences at the Massachusetts Institute of Technology. She received a Ph.D. from the Stern School of Business at New York University. Her primary research interests focus on the recursive relationship between organizations and information technology, with particular emphasis on organizing structures, cultures, work practices, and change. She can be reached at wanda@ MIT.EDU. 
JoAnne Yates is Sloan Distinguished Professor of Management at the Sloan School of Management, Massachusetts Institute of Technology. JoAnne examines communication and information as they shape and are shaped by technologies, ideologies, and work practices over time, both in today's organizations and in organizations historically. In her contemporary work, JoAnne studies communication and work practices around electronic communication media in organizations, focusing on genres and on temporal and communication practices. She has published on these topics in Administrative Science Quarterly, Organization Science, and elsewhere. She can be reached at jyates@MIT.EDU. 